\title{
Białowieża Primeval Forest as a remnant of culturally modified ancient forest
}

\author{
Andrzej Bobiec
}

Received: 29 August 2011/Revised: 17 December 2011/ Accepted: 3 January 2012/Published online: 11 February 2012

(C) The Author(s) 2012. This article is published with open access at Springerlink.com

\begin{abstract}
The present and past population status of oak (Quercus robur) in the Białowieża National Park preserve (BNP) was analyzed with respect to the historic use of the ecosystem. I assessed average parameters (density, dbh distribution, differences between habitat categories) of the oak population in the whole BNP preserve, and performed detailed analyses of local populations on three 26.5-ha and one 3.5-ha plots, representing eutrophic sites of deciduous forest (3) and a mesotrophic site of mixed forest (1). Based on the tree ring data, I reconstructed the historic dbh distribution back to 1750-1825. The results of the reconstruction confirm the early 1800 s expert account and the 1889 forestry survey report. The high oak concentration in eutrophic habitats are legacies of either active game management (e.g., bison habitat improvement measures, supplementary feeding), forest recovery after the ban on forest industries (baking potash, tar, charcoal), or abandonment of inner small farms. The emergence of oak on poorer sites in the mid 1800 s coincides with the ban on use of fire-a common practice that earlier had perpetuated the dominating position of fire-resistant pine. The present oak regeneration in declining spruce stands is a further step of the forest natural adaptation to environmental changes. The study supports the view that BNP is a remnant of an ecosystem substantially shaped by human uses. Modern forestry, as practiced in the managed part of the Białowieża forest, does not mimic either natural processes (as observed in BNP) or historic forest uses.
\end{abstract}

Communicated by A. Weiskittel.

A. Bobiec $(\square)$

Faculty of Biology and Agriculture, Agroecology and Landscape

Architecture, Rzeszów University, ul. M. Ćwiklińskiej 2,

35-601 Rzeszów, Poland

e-mail: a_bobiec@univ.rzeszow.pl
Keywords Abandoned farmland - European bison . Fire · Forest history - Quercus robur regeneration . Spruce decline

\section{Introduction}

The notion "primeval forest" is commonly used as translation of the Slavic word "puszcza" (pushcha) meaning desertum, a vast uninhabited area, which in temperate Europe used to be forests. There are dozens of forest areas in Poland that retained word "puszcza" in their name: Puszcza Białowieska, Puszcza Knyszyńska, Puszcza Augustowska, Puszcza Romincka, Puszcza Borecka, just to mention only few from the NE province of Poland. Although translation of the historic/geographic name into a concept having a clear ecological connotation can be misleading, there are strong reasons to emphasize the uniqueness of the Białowieża forest.

Although the Białowieża Primeval Forest (BPF), straddling the border between Poland and Belarus, is commonly perceived as an important reference for the temperate zone of lowland Europe, there is no consent regarding the degree of its naturalness. Even if the dispute is confined to the area of the Białowieża National Park (BNP) preserve (granted strict protection in early 1920s), the views on its naturalness range from that of virgin forest (Paczoski 1930; Faliński 1986; Peterken 1996) to an artifact of deliberate management/preservation policy (Vera 2000). The disagreement does not refer to whether or not there was any human intervention (there is a great deal of an evidence of human activities from that area, e.g., Karcev 1903; Paczoski 1930; Borowik-Dąbrowska and Dąbrowski 1973; Faliński 1986), but to the role such human activities would have played in ecosystem development. While for the 
followers of the idea of the "relict primeval forest," man was inducing a mere disturbance to the unbroken, overriding natural course, the advocates of the large herbivore grazing concept argue that ancient forest pastoralism, mimicking primal ecosystem dynamics, overwhelmed forest development until the 19th century (Vera 2000).

The resolution of this debate will fundamentally affect how we perceive the role of "reference area" that BPF has long been considered with regard to other forests of temperate zone of the European lowland. Is it a relic of primeval ecosystems, a "window into the past" (Tomiałojć and Wesołowski 2005), showing how would forests look and function if they were not subject to major anthropogenic disturbances? Or, should it rather be perceived as an old "laboratory" of nature adapting remnants of culturally shaped ecosystems to the present environmental conditions? While the former would entail relatively stable and resilient forest communities, subject to various fluctuations, the latter would be reflected by progressive changes. Depending on the resolution, there will be different applicabilities of the "reference area" in the practice of management and conservation of European temperate forests.

The dilemma was partly resolved by Niklasson et al. (2010) who revealed that the overwhelming domination of pine (Pinus sylvestris) in BPF in the past was an effect of the long history (from 1500s to 1700 s) of frequent ground fires. Only the ban on the use of fire imposed by the forest administration in early 1800 s allowed the BPF to develop the fire-prone spruce (Picea abies) and mixed stands (Niklasson et al. 2010). As this is clear evidence of directional changes leading to dynamic equilibrium, our observations of contemporary mixed and conifer-dominated BPF stands do not represent a primal ecosystem, but a snapshot of the unfinished and continuing process leading from historic culturally shaped pine stands to future natural forest communities.

This conclusion, however, is not necessarily applicable to forest communities which were not subject to such a ground fire regime, including conspicuous old-growth stands of lime-oak-hornbeam (Tilio-Carpinetum) communities, commonly identified as true remnants of primal ecosystems (Faliński 1986; Peterken 1996; Bobiec 2002a). Although they are dominated by shade-tolerant hornbeams (Carpinus betulus) and limes (Tilia cordata), impressive pedunculate oaks (Quercus robur) imprint a special character on such stands.

N. Genko assigned the tree species occurring in the BPF to two different categories. While most species have specific requirements for forest site, oak, birch (Betula pendula and B. pubescens), and aspen (Populus tremula) are site indifferent ("can grow more-or-less everywhere"Genko 1902-1903). His observation, in particular regarding oak, clearly contrasts with the common perception of
Q. robur as a major canopy species of rich deciduous forests (e.g., Faliński 1986; Ellenberg 1988; Sokołowski 1993). However, already in the early 1900s there were studies revealing oak's exceptional qualities as a successful colonizer (Watt 1919) and a skilled opportunist adapting to sites with weaker competition from tolerant trees (Paczoski 1930). As it was recently demonstrated both strategies were being still in use in the BPF area (Bobiec et al. 2011a, b).

The broad ecological niche of oak together with its dependence on disturbances on rich sites (Vera 2000; Bobiec 2007; Bobiec et al. 2011a) and its longevity make its populations potentially a very valuable source of the information on the past dynamics of forests.

In this paper, I present results of the reconstruction of the oak population development since 1700 s, based on tree density and dbh (diameter measured at $1.3 \mathrm{~m}$ ) structure analyses, tree ring data, and spatial information. This reconstruction has been compared to historic topical publications of Brincken (1826); Genko 1902-1903, and Karcev (1903). With a negligible rate of contemporary regeneration of oak in Tilio-Carpinetum forest (Bernadzki et al. 1998; Vera 2000; Brzeziecki 2008; Bobiec et al. 2011a), the study aims at finding which circumstances allowed oak to regenerate in the past and to establish its strong position in the contemporary old-growth canopy.

\section{Materials and methods}

\section{Study area}

\section{Historical context}

Until World War I, the entire forest had a special protective status. Since the 1400s the BPF was a royal hunting ground which involved making numerous concessions to noble families and royal forest wardens. Concessions included the right to settle clearings and use of ground by wardens' families, acquire wood for their households' needs, hay making in oak and riparian forests, beekeeping mainly in pine forests, constructing dams on forest rivers for fishing, charcoal, potash, tar, and pitch making, as well as hunting smaller game (grouse, hare, roe deer) (Samojlik and Jędrzejewska 2004). At the same time, the major part of forest was set aside as a hunting preserve (game wild refuge area), where no use was allowed except for royal hunts. Although no historical map nor sketch of the BPF protection and use has been found, Samojlik and Jędrzejewska (2004) reconstructed the approximate location and range of a number of concession enclaves.

Major modifications to the BPF management occurred in the 1700s when systematic bison feeding began and inner concessions were invalidated. The 1800 s were the time of 
unsuccessful attempts to reconcile modern forestry with important conservation goals. Due to the lack of suitable transportation routes and very limited local demand for raw material, the extent of wood extraction remained very limited (Genko 1902-1903). In addition, the exploitation was confined mainly to pines felled in the "non-bison," i.e., peripheral, zone of the BPF (Genko 1902-1903).

Data collection took place in the centrally located preserve of the BNP (N 52.74, E 23.87, 4747 hectares = ca. $8 \%$ of the Polish part of the BPF), set aside in 1916. Dominated by deciduous stands and neighboring to the south with Białowieża village (location of the 1500s' royal castle), it is highly probable that the BNP preserve or at least a substantial part used to belong to the royal game preserved refuge. Although it avoided major felling campaigns of 1800s' targeting pine (Genko 1902-1903), some oaks might have been felled in mid 1800 s for naval construction. That project was quickly canceled due to inadequate technical quality of wood (core rot) and extremely difficult and expensive transportation (Genko 1902-1903).

Since World War I, the BPF area outside the preserve was subject to systematic forest management, only recently modified by the enlargement of the national park in 1996 (to ca. 10,000 hectares) and establishment of the network of forest reserves.

\section{Physiographic conditions}

The basic framework of BPF communities' structure and function is determined by continental climate (average annual precipitation of $641 \mathrm{~mm}$, ranging from 426 to $940 \mathrm{~mm}, 85 \%$ in rain; average annual temperature of $6.8^{\circ} \mathrm{C}$, ranging from 5.1 to $8.8^{\circ} \mathrm{C}$, with the average temperature in July ranging from 15.2 to $21.6^{\circ} \mathrm{C}$ and in January from -13.4 to $1.8^{\circ} \mathrm{C}$; Olszewski 1986), the postglacial geological formation (vast plains with small altitude differences-from 134 to $202 \mathrm{~m}$ a.s.1.), and its location within the continental watershed (Faliński 1986). These conditions are reflected by the specific position of the forest regarding the range of several tree species, such as missing beech, sycamore, yew, and large-leaf lime, as well as very limited number of sessile oak at its eastern range limit. At the same time, Białowieża lies in the southernmost part of the spruce boreal range, making this species very responsive to climate changes, drought, and summer heat.

\section{Literature study}

I collated the data from two historical references, Brincken (1826) and Genko 1902-1903, with particular respect to the information on stand composition and dynamics, as well as to factors that used to shape the BPF ecosystems. From Karcev (1903) I adapted the forest maps, most probably based on the same forest inventory (1889) analyzed by Genko 1902-1903. I have re-calculated and transformed the tabular data on stand structure provided by the latter author in obsolete Russian units to metric units. As a contemporary reference I used the data on dbh structure of stands of the BNP preserve from Sokołowski (1993), adapted to the dbh intervals used by N. Genko. I also referred to the ecological and botanical observations of BPF by J. Paczoski in early 1920s (Paczoski 1930).

\section{Field study}

\section{The whole preserve area}

The systematic inventory (georeferencing and callipering) of oaks taller than $1.3 \mathrm{~m}$ was performed on $100 \times 20-\mathrm{m}$ plots $(N=533)$ set every hundred meters perpendicular to ca. 55-km-long sampling lines in the BNP area. Apart from most of the lines following the boundaries of regular compartments and the old forest road, I set several additional lines to depict specific zones: edge along the border of mesic forest and vast flooded zone (Edge), edge along mesic forest and narrow flooded zone (Riverside), as well as along the border of the former fodder clearings (Clearing) (Fig. 1; Table 1). The purpose of using such additional sampling lines was to test whether the actual or former ecotone zones (verge of the wide flood area, edge of the narrow riverside, and edge of fodder clearings, abandoned in early 1900s) differ in their oak population densities from the average in the preserve. To compare oak population density in mesic deciduous forest with mixed forest-only compact parts of sampling plots, larger than $1,000 \mathrm{~m}^{2}$, representing a single site category, were considered (Table 1).

\section{Case areas}

To explore the oak population characteristics at local scales, I set three 26.5 -ha $(515 \times 515-\mathrm{m})$ plots in arbitrarily chosen locations of high and low oak population densities in rich deciduous forest (areas A and B), and in poorer, mesotrophic sites of mixed forest (C). In addition, one irregular 3.5-ha plot (F) represented the area occupied by the historic agricultural enclave (Figs. 1, 2). All oaks in those plots were georeferenced and their dbh were measured.

\section{Tree ring data}

In four case areas, I cored with the 5-mm Pressler's increment gauge all dead oaks (both snags and down logs) with preserved hard wood: 54 in plot A (plus 11 live trees), 8 in B (plus 7 live trees), 43 in C (plus 6 live trees), and 14 in $\mathrm{F}$ (only dead trees and $\operatorname{logs}$ ). Based on the eye assessment of sampled trees (presence/absence of twigs, small 


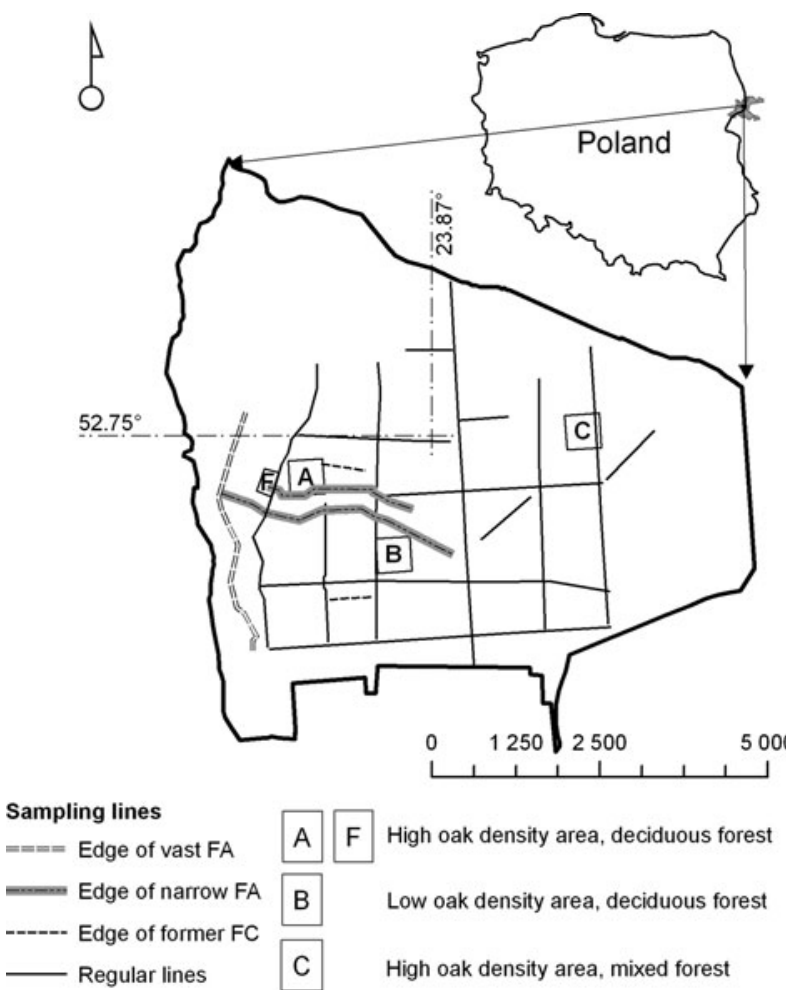

Fig. 1 Study area: the preserve of the Białowieża National Park (BNP); $F A$ flooded area, $F C$ fodder clearing, $H D$ high oak density, $L D$ low oak density, $F F$ former farm

branches, retention of bark, decay progress), I estimated the approximate time lapse since their death using broad intervals of $0-5,5-10,10-20$, and $>20$ years. The wood samples were glued to wooden slats, polished with 800-p sand paper, and the rings were measured with the LINTAB-5 device. All dead tree series were cross-dated with the chronology calculated from the available live trees series. The best matches were found with the manual crossdating procedure available in TSAP-Win v. 4.65 software (2002-2010 Frank Rinn, RINNTECH). Positions of dead tree series were determined by the highest values of the Cross-Date Index (being a combination of percentages of parallel variation (Gleichlaeufigkeit, Glk), a measure representing overall accordance of two series, and $t$ value reflecting correlation significance) and the Glk significance (Rinn 2003). As an additional measure, I verified whether the years of the latest rings of the dated series corresponded with the estimated years of tree death.

In case of samples missing pith, I used the pith-finder stencil that adjusted to sample's rings and rays provided an estimated distance from pith to the first recorded ring. Based on this distance and the average ring width, I calculated the number of missing years. For samples with estimated distance to the pith shorter than $10 \mathrm{~mm}$ I used only the ten oldest rings, while for other samples I applied the all-series averages. If the number of added rings made less than $10 \%$ of the overall estimated series length, I considered such estimate of the pith age reliable and displayed it on the area map of Fig. 3.

The basis for the backward reconstruction of the historic oak dbh structure was the information on the average annual ring width within particular time intervals estimated from sampled oaks. For instance, knowing the average dbh increment between 1950 and 2010, its subtraction from the 2010 's dbh of a given tree makes the estimated dbh of that tree in 1950. However, following the assumption that there is no strong dbh correlation with the tree age, in order to improve reliability of the dbh reconstruction, I calculated separately average increments for subsets of sampled oaks

Table 1 Basic oak statistics based on the $100 \times 20$-m sampling plots perpendicular to sampling lines and four study case areas (see Fig. 1)

\begin{tabular}{|c|c|c|c|c|c|c|c|c|}
\hline \multicolumn{3}{|l|}{ Sampling units } & \multicolumn{3}{|c|}{ Oak population density } & \multicolumn{2}{|c|}{ Number of trees } & \multirow{2}{*}{$\begin{array}{l}\text { Dbh }(\mathrm{cm}) \\
\text { SE }\end{array}$} \\
\hline & Length/area & $N$ & $\mathrm{~N} \mathrm{ha}^{-1}$ & SE & Median & & Mean & \\
\hline Regular & $4,3613 \mathrm{~m}$ & 432 & $12.7^{\mathrm{u} 1}$ & 0.7 & 8.6 & 1269 & $66.3^{\mathrm{c}}$ & 0.9 \\
\hline Riverside & $6,070 \mathrm{~m}$ & 54 & $10.2^{\mathrm{u} 1}$ & 1.7 & 8.6 & 127 & $84.6^{\mathrm{ab}}$ & 2.9 \\
\hline Edge & $3,817 \mathrm{~m}$ & 33 & $3.5^{\mathrm{u} 2}$ & 1.0 & 0.0 & 27 & $77.4^{\mathrm{abc}}$ & 7.2 \\
\hline Clearing & $1,311 \mathrm{~m}$ & 14 & $1.9^{\mathrm{u} 2}$ & 0.9 & 0.0 & 6 & $111.1^{\mathrm{bc}}$ & 19.5 \\
\hline Total/average & $54,811 \mathrm{~m}$ & 533 & 11.6 & 0.6 & 8.6 & 1429 & 68.3 & 0.9 \\
\hline Deciduous forest & 66.4 ha & 389 & 11.3 & 0.8 & 6.3 & 767 & $74.4^{\mathrm{a}}$ & 1.2 \\
\hline Mixed forest & 14.2 ha & 84 & 17.0 & 1.9 & 12.7 & 246 & $52.1^{\mathrm{e}}$ & 1.7 \\
\hline Plot A (90\% DF) & 26.5 ha & 1 & 15.6 & & & 415 & $75.9^{\mathrm{a}}$ & 1.5 \\
\hline Plot B (99\% DF) & 26.5 ha & 1 & 4.8 & & & 130 & $92.7^{\mathrm{b}}$ & 3.0 \\
\hline Plot C (99 MF) & 26.5 ha & 1 & 12.1 & & & 322 & $23.6^{\mathrm{d}}$ & 1.4 \\
\hline Plot F (100\% DF) & 3.5 ha & 1 & 21.1 & & & 74 & $83.3^{\mathrm{ab}}$ & 3.0 \\
\hline
\end{tabular}

${ }^{\mathrm{a}-\mathrm{e}}$ HSD homogenous groups $(\alpha=0.05)$

u1, u2 Pairs of densities that not differ significantly (U Mann-Whitney, $p>0.100$ ) 
Fig. 2 The area of today's BNP preserve with forest types and the area accessed by livestock at the end of 1800 s, adapted from the historic maps from Karcev (1903); three historic fodder clearings (of the 1800s) and the position of the 1700s' small settlement with farm located on the basis of the BNP digital map of stands and Borowik-

Dabrowska and Dabrowski (1973)

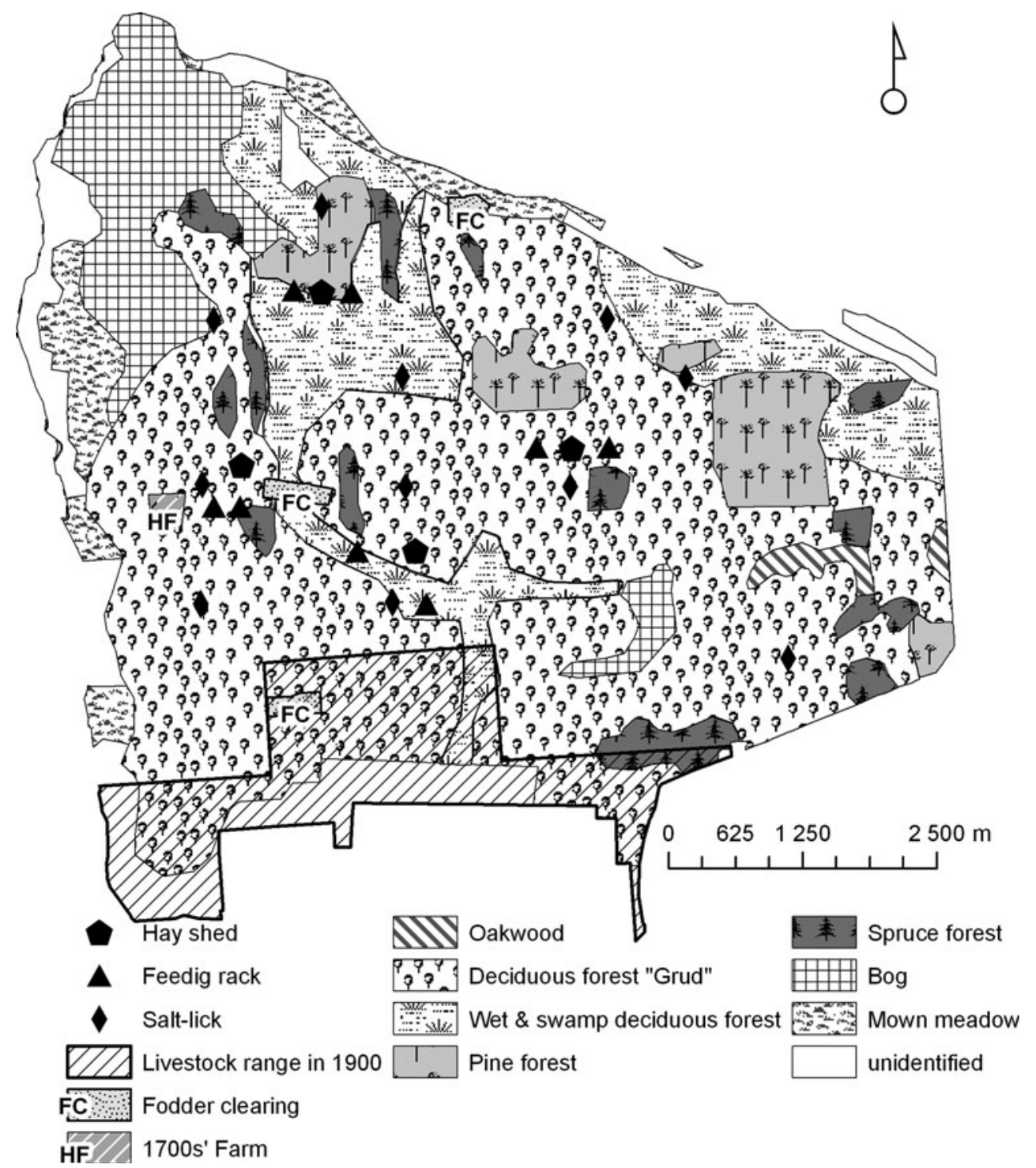

representing certain dbh classes. The number, width, and end values of intervals depended on the size and diameter distribution of the sampled oak subpopulations (Table 2). To test the ring width differences between particular dbh categories, I compared the increment within 1916-1980, i.e., the preservation period within which almost all series were fully represented by 65 rings. For the actual estimates of increments in particular periods (e.g., 1925-2010), I used dbh category-specific averages weighed with the number of rings representing a particular series in the given period. The oaks of which dbh estimates fell within the $0-10$-cm interval in a given year (e.g., 2010, 1875) were considered to recruit shortly prior to that year and were adequately represented on the map (Fig. 3). The achieved historic oak frequencies in particular dbh classes are underrated because mortality was not taken into consideration.

\section{Statistical analysis}

The $\mathrm{G}$ test for independence (McDonald 2009 and Sokal and Rohlf 1995 cited therein) was used to test the difference in the extent of particular forest types in the BNP area between 1889 and 1990. The distributions of oak densities between regular, floodplain, riparian, and clearing edge habitats were compared with U Mann-Whitney statistics, and the differences between the oak population densities in case areas and average densities in particular forest types were compared with $2 \times 2$ contingency tables. The mean dbh of the cored (mainly dead) oaks was compared to the mean dbh of all living oaks in the case areas with the t-test. In the case of $\mathrm{C}$ area, oak saplings ( $\mathrm{dbh}<7 \mathrm{~cm}$ ) were not considered in the mean dbh calculation, while in three other case areas all oaks were considered as they had only larger oaks. To test the within- and between-group (defined 
Fig. 3 Position of living oaks in A-F case areas (see Fig. 1 for their location); symbols: Older- "veteran" oaks, apparently emerged in early 1700 and earlier, 1750-1900oaks with dbh below $10 \mathrm{~cm}$ in those years, 1900s-dbh below $10 \mathrm{~cm}$ in 1901-1985, 2010dbh below $10 \mathrm{~cm}$ in 2010 ; kilns-man-made mounds, apparently potash baking ( $\mathrm{T}$. Samojlik pers. communication); numbers within the plot boundaries-years in which dated (mainly dead) oaks had reached the height of $1.3 \mathrm{~m} ; \mathrm{Pa} /$ Ps90, 120, 170-stand dominated by $90-, 120-$, 190-year-old spruce/pine, MOS/ MES-meso-oligotrophic/ eutrophic site (Michalczuk 2001)
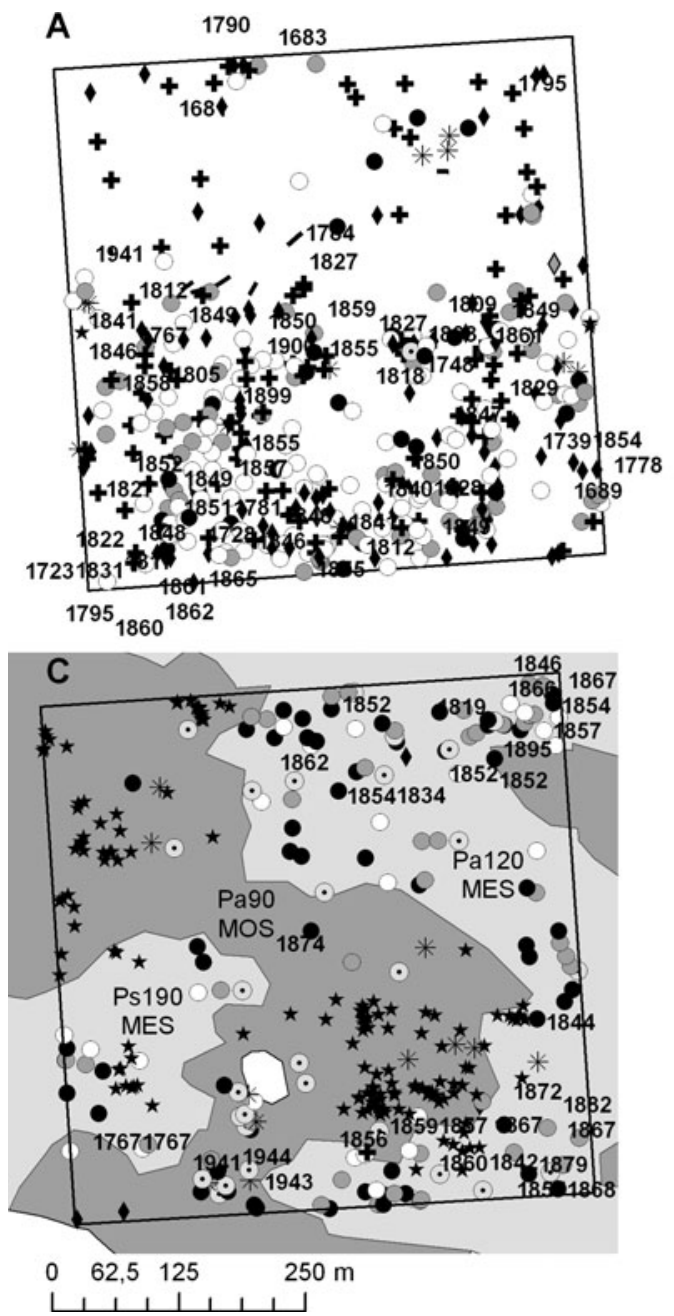

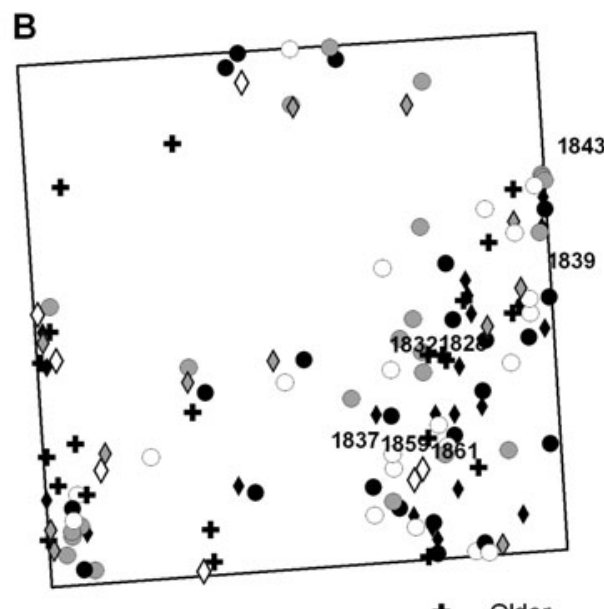

$\mathbf{F}$

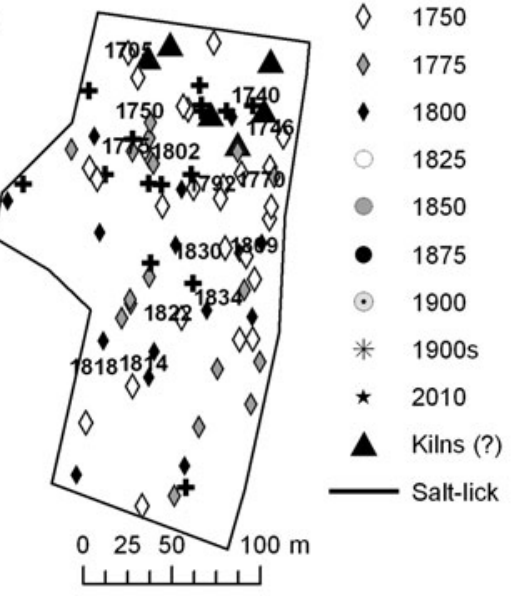

Table 2 Basic characteristics of the cored oaks subsamples: $N$-number of cored trees (number of dated trees for which the estimated $\%$ of rings missing to the pith was below 10)

\begin{tabular}{|c|c|c|c|c|c|}
\hline Case area & $N$ & Cored versus all live oaks average dbh & Dbh intervals $(\mathrm{cm})$ & Dbh inc & lent in 1916-1980 (cm) \\
\hline A & $65(56)$ & $\begin{array}{l}66.0 \text { versus } 75.9 \mathrm{~cm} \\
t=2.929, d f=507, p=0.004\end{array}$ & $\begin{array}{l}\leq 40 \\
>40-60 \\
>60-80 \\
>80-100 \\
>100\end{array}$ & $\begin{array}{l}12.4^{\mathrm{a}} \\
20.8^{\mathrm{c}} \\
27.0^{\mathrm{bc}} \\
28.1^{\mathrm{b}} \\
21.2^{\mathrm{abc}}\end{array}$ & $F=10.170 ; d f=4 p \ll 0.001$ \\
\hline B & $15(7)$ & $\begin{array}{l}72.7 \text { versus } 92.7 \mathrm{~cm} \\
t=2.184, d f=143, p=0.031\end{array}$ & $\begin{array}{l}\leq 50 \\
>50-75 \\
>75\end{array}$ & $\begin{array}{l}12.2 \\
24.6 \\
39.0\end{array}$ & $H_{2, N}=15=11.025 p=0.004$ \\
\hline $\mathrm{C}$ & 49 (32) & $\begin{array}{l}42.8 \text { versus } 43.5^{\mathrm{d}} \mathrm{cm} \\
t=0.247, d f=220, p=0.805\end{array}$ & $\begin{array}{l}\leq 30 \\
>30-50 \\
>50\end{array}$ & $\begin{array}{l}13.8^{\mathrm{a}} \\
15.7^{\mathrm{a}} \\
22.9^{\mathrm{b}}\end{array}$ & $F=8.427 ; d f=2 p<0.001$ \\
\hline $\mathrm{F}$ & $14(14)$ & $\begin{array}{l}74.0 \text { versus } 83.3 \mathrm{~cm} \\
t=1.304, d f=122, p=0.195\end{array}$ & $\begin{array}{l}\leq 60 \\
>60-80 \\
>80\end{array}$ & $\begin{array}{l}16.6 \\
14.6 \\
25.6\end{array}$ & $\begin{array}{l}H_{2, N}=14=7.221 \\
p=0.027\end{array}$ \\
\hline
\end{tabular}

${ }^{\mathrm{a}-\mathrm{c}}$ HSD homogenous groups $(\alpha=0.05) ; \mathrm{F}$ and $\mathrm{H}-\mathrm{ANOVA}$ and Kruskal-Wallis rank ANOVA statistics, respectively

${ }^{\mathrm{d}}$ Only oaks with $\mathrm{dbh} \geq 7 \mathrm{~cm}$ 
dbh categories) variability of oak dbh increment in 1916-1980, I applied one-way ANOVA and the post hoc HSD Tukey test for unequal samples for $\mathrm{A}$ and $\mathrm{C}$ cases, and Kruskal-Wallis ANOVA for ranks for B and F cases, due to their small sample sizes.

All statistical tests except for $G$ test (performed in the Excel spreadsheet provided by McDonald 2009) were done in Statistica v. 9.1 (StatSoft, inc. 1984-2010). Both histograms and the reconstruction were made with MS Excel.

As a backdrop for the cartographic work, I used the 1991 forest inventory data (Michalczuk 2001) upgraded to digital map format and provided by the BNP administration. For digitizing and adapting the historic maps of the BPF, I used ArcGIS ArcView 9.3 (ESRI, inc. 1993-2008).

\section{Results and discussion}

Forest sites and stands according to the historic and contemporary data

The 1889 forest inventory classified the forest using the traditional system from the 1500s. According to that typology, the BPF consisted of pine forest ("bor," "lado") on sandy soils, black forest ("chernoles") on richer and usually wetter soils, and bog ("bagon"). Black forest was subdivided into rich deciduous forest on mineral soil ("grud," equivalent of Tilio-Carpinetum), pure spruce stand on organic soil ("yelosmych"), and flooded and swampy alder forest ("oles," including both alder swamp and riparian forest) (Genko 1902-1903, Table 3).

As shown in Table 3, the report by J. von Brincken (1826), the then chief forester of the Polish province of Russia, and the detailed analysis of the results of the 1889's BPF survey presented by Genko 1902-1903 provide a consistent picture of the historic forest's characteristics. These two publications refer to the whole BPF area, split since 1945 by the state border with USSR.

According to the first author, pure pine stands occupied ca. $80 \%$ of the BPF area in the 1820s (Brincken 1826). Sixty years later, the detailed inventory revealed that pinedominated stands covered $63 \%$ and reported a massive encroachment of spruce into almost all kinds of forest types, allegedly caused by the "no fire" policy imposed after the 1811's fire (Genko 1902-1903, Table 3; Fig. 4). This interpretation of the forest inventory data is very consistent with Brincken's (1826) observations that in the 1820 s spruce occurrence was limited to rich deciduous forest as well as wet and swampy areas (Table 3). As pure pine forests would naturally occur only on poorest sites such as eolic sand dunes and acidic bogs, habitats that are very rare in the BPF, the fact that almost $40 \%$ of the forest was "lado" in 1889 (Table 3) can only be explained by the impact of ground fires that select against species less resistant to fire.

Because the lower threshold of the dbh data provided by $\mathrm{N}$. Genko was only $11 \mathrm{~cm}$, it is very probable that much of the pine forest had already a rich spruce, birch, or other species undergrowth developed. Therefore, pine forest subtypes as distinguished by Genko 1902-1903 would have depended on the length of time since the last fire as well as on the soil richness. While pine forest with oak was probably the effect of the longest period of succession on relatively rich sites, pine with birch represented the early successional stage, and the domination of young spruce would occur on poorer sites than those used by oak (Table 3; Fig. 4). This is also congruent with J. Paczoski's remarks on oak regeneration in the BPF. He emphasized that the species is most successful (in regeneration and recruitment) on poorer sites, including pine forest, where it gains competitive advantage over other trees of higher demands with regard to soil richness. The author put oak after pine and birch and before aspen, hornbeam, maple (Acer platanoides), and ash (Fraxinus excelsior) with elm (Ulmus sp.) in an ecological series regarding edaphic requirements and successional order (Paczoski 1930).

Unlike contemporary researchers, defining rich deciduous forest on mineral soil (Tilio-Carpinetum, "grud") as lime-oak-hornbeam forest (Faliński 1986; Ellenberg 1988; Sokołowski 1993) for N. Genko "grud" was not a typical habitat for oak. As he had shown, this site-indifferent species would more likely regenerate using its competitive advantage on fire-freed coniferous sites (Table 3; Genko 1902-1903). This is particularly clear while comparing the dbh frequency distribution based on the 1889 inventory results (Fig. 4).

This does not contradict the Brincken's (1826) observation of "colossal" oaks in enclaves of deciduous forest (Table 3). His description does not differ from contemporary accounts, both based on a general impression rather than on demographic analysis of their population (Faliński 1986; Peterken 1996; Bobiec 2002a).

The patterns detected from the results of the 1889s forest inventory can still be identified 100 years later. The composition and structure of mixed-coniferous forest, or $\mathrm{Ca}$ lamagrostio-Piceetum (Sokołowski 1993), is very similar to that of pine forest with spruce (Genko 1902-1903), but they could have developed from "lado" pine forest where spruce undergrowth was already present in the late $1800 \mathrm{~s}$. Similarly, mixed deciduous forest, or Melitti-Carpinetum (Sokołowski 1993), has a strong affinity to Genko's 19021903 pine forest with oak. The major difference between Genko's 1902-1903 "grud" and Sokołowski's (1993) Tilio-Carpinetum is a relatively abundant presence of young lime trees in the late 1900s, a species represented only by 
Table 3 Comparison of the Białowieża Primeval Forest (BPF) characteristics based on the first concise naturalist report by J. von Brincken and on the results of the 1889 forest inventory provided and analyzed by N. Genko

\begin{tabular}{|c|c|c|c|}
\hline \multicolumn{2}{|c|}{ Brincken (1826); Total BPF area: 93,666 ha } & \multicolumn{2}{|c|}{ Genko 1902-1903; Total BPF area: 101,908 ha (wooded: 87,538 ha) } \\
\hline \multirow[t]{5}{*}{$\begin{array}{l}\text { Pine } \\
\text { forest }\end{array}$} & \multirow{5}{*}{$\begin{array}{l}\text { 80\% of the BPF; Very uneven stands regarding spatial } \\
\text { distribution, height, age, and diameter; Huge old pines } \\
\text { dispersed irregularly here and there; All other age } \\
\text { classes abundant; Large amount of dead wood; At the } \\
\text { transition from sand to richer sites pines sometimes } \\
\text { mixed with oaks, birches, and aspens, regenerating } \\
\text { particularly on clearings; There are also large forest } \\
\text { segments representing dense even-aged pine stands } \\
70-90 \text { years old as well as smaller patches of young } \\
\text { thickets, both effects of large-scale disturbances, such } \\
\text { as storms, fire, and insect infestations - e.g., such } \\
\text { abundant pine regeneration is observed in the area } \\
\text { destroyed by the } 1819 \text { big fire; Local people } \\
\text { successfully practice prescribed burning applying } \\
\text { "counter-fire"-such ground fires do not destroy } \\
\text { uneven pine forest }\end{array}$} & $\begin{array}{l}\text { "Lado" } \\
39.2 \%\end{array}$ & $\begin{array}{l}\text { As "lado" occurred on poorest sandy soils, mostly in SE } \\
\text { part of the BPF; other pine forest subtypes developed } \\
\text { on richer soils; spruce subtype mainly observed on the } \\
\text { transition to "chernoles"; best pine regeneration after } \\
\text { fire and on abandoned pastured clearings on poor soils; } \\
\text { Fire intentionally set by shepherds and beekeepers }\end{array}$ \\
\hline & & + oak $2.6 \%$ & "incorrect" exploitation of pine at the end of $1700 \mathrm{~s}$, in \\
\hline & & & $1840,1850,1870$, and $1880 \mathrm{~s}$ \\
\hline & & $\begin{array}{c}+ \text { spruce } \\
13.5 \%\end{array}$ & \\
\hline & & Bog $1.1 \%$ & \\
\hline \multirow[t]{3}{*}{ Chernoles } & $\begin{array}{l}\text { Compact spruce forest near the district Nieznanów (in the } \\
\text { same NW part of the BPF-there is nature reserve of } \\
\text { spruce boreal forest "Sphagno-Piceetum") }\end{array}$ & $\begin{array}{l}\text { Yelosmych } \\
7.1 \%\end{array}$ & $\begin{array}{l}\text { Spruce forest with aspen; pine never seen; the description } \\
\text { corresponds with the characteristic of the boreal } \\
\text { "Sphagno-Piceetum" forest }\end{array}$ \\
\hline & \multirow{2}{*}{$\begin{array}{l}\text { Deciduous forest: multiple patches in the matrix of pine } \\
\text { forest; Dominating canopy made up of enormous oaks } \\
\text { and limes with few ashes, maples, and elms; Space } \\
\text { between trees of the dominant height occupied by } \\
\text { hornbeams, poplars (aspens?), birches, alders, and } \\
\text { willows; Spruce mixed with deciduous trees well seen } \\
\text { from a distance due to its eminent height; Pine never } \\
\text { occurs; Very dense, a lot of dead wood; Sometimes } \\
\text { neighbor with rich wet meadows }\end{array}$} & Grud $15 \%$ & $\begin{array}{l}\text { Forest on rich but not damp sites; dominated by } \\
\text { hornbeam, maple, elm, and lime }\end{array}$ \\
\hline & & Oles $15 \%$ & $\begin{array}{l}\text { Swampy forest dominated by alder and ash (no } \\
\text { distinction between alder swamp and riparian forest) }\end{array}$ \\
\hline Oak & $\begin{array}{l}\text { Usually on richer soils, not too wet, but sometimes also } \\
\text { observed on sandy soils among pines }\end{array}$ & \multicolumn{2}{|c|}{$\begin{array}{l}\text { Site indifferent; Constitutes the admixture to all kinds of mixed stands, } \\
\text { except for "mossy bogs"; Most typically larger groups occur in the } \\
\text { transition from pine to deciduous forest as well as from deciduous } \\
\text { "dry" (grud) to swampy alder (oles) forest, everywhere else single } \\
\text { individuals }\end{array}$} \\
\hline Spruce & $\begin{array}{l}\text { Devastations of spruce by bark beetle are unknown here } \\
\text { as the tree is mixed with deciduous trees or it occurs in } \\
\text { wet sites unsuitable for the insect mass-breeding }\end{array}$ & \multicolumn{2}{|c|}{$\begin{array}{l}\text { Very few old trees; Since } 1820 \text { s mass encroachment of spruce to most of } \\
\text { types of forest caused by burning prohibition }\end{array}$} \\
\hline $\begin{array}{r}\text { Bison } \\
\text { data }\end{array}$ & 700-800 individuals & \multicolumn{2}{|c|}{$\begin{array}{l}\text { in } 1828-696 \text { individuals; } 1829-711 ; 1832-760 ; 1850-1510 \text {; } \\
1850-1510 ; 1857-1898 ; 1858-1434 ; 1860-1575 ; \text { in } 1860 \text { s fall to ca. } \\
400\end{array}$} \\
\hline
\end{tabular}

few larger specimens per hectare a 100 years earlier (Fig. 4).

The latter inference does not reflect the conclusions from observations of stand development on five permanent plots (total area 14.9 ha including rich deciduous forest 8.6 ha) set in 1936 in the BNP preserve area (Bernadzki et al. 1998). According to Brzeziecki (2008), the observed changes represent a more general trend eventually leading to a total domination of hornbeam in the canopy layer. However, the comparison of the 1889 and late 1900s data representing a broader extent of deciduous forest (i.e., the entire BPF and entire BNP preserve, respectively) show that the true "outbreak" of hornbeam regeneration (as well as that of spruce) took place in the late 1800 s, when its density in the lowest recorded class $11-20 \mathrm{~cm}$ was twice as high as today (Fig. 4).

As shown in Table 4, the major differences between the proportions of the area occupied by five types of habitat categories at the end of 1800 s and in late 1900 s concern pine and spruce forest, bog, and open area. While the increase of spruce forest can easily be explained by the natural processes following the ban on use of fire, the larger share of pine in 1990 compared to 1889 could partly be caused by the difference in inventory criteria applied by surveyors: part of habitats defined in 1889 as bog in 1990 were classified as bog coniferous forest or bog mixed forest (Michalczuk 2001)—categories not used 100 years earlier. A more likely cause of open area in the late 1800s was the 
Fig. 4 Frequency distribution of trees in dbh intervals according to the BPF 1889 forestry survey contrasted with distribution of trees in 1993 (Sokołowski 1993); the irregular intervals correspond to the original figures provided by Genko 1902-1903 in obsolete Russian length units "vershok" $(=4.445 \mathrm{~cm})$; right column figures are from the transformation of Sokołowski's (1993) original data from multiple small measurement plots (total area provided) in 4-cm intervals to Genko's irregular intervals. Bold numbers in upper parts of Sokolowski's three plots: total number of spruce trees in lowest dbh intervals; hectares: total survey/research area
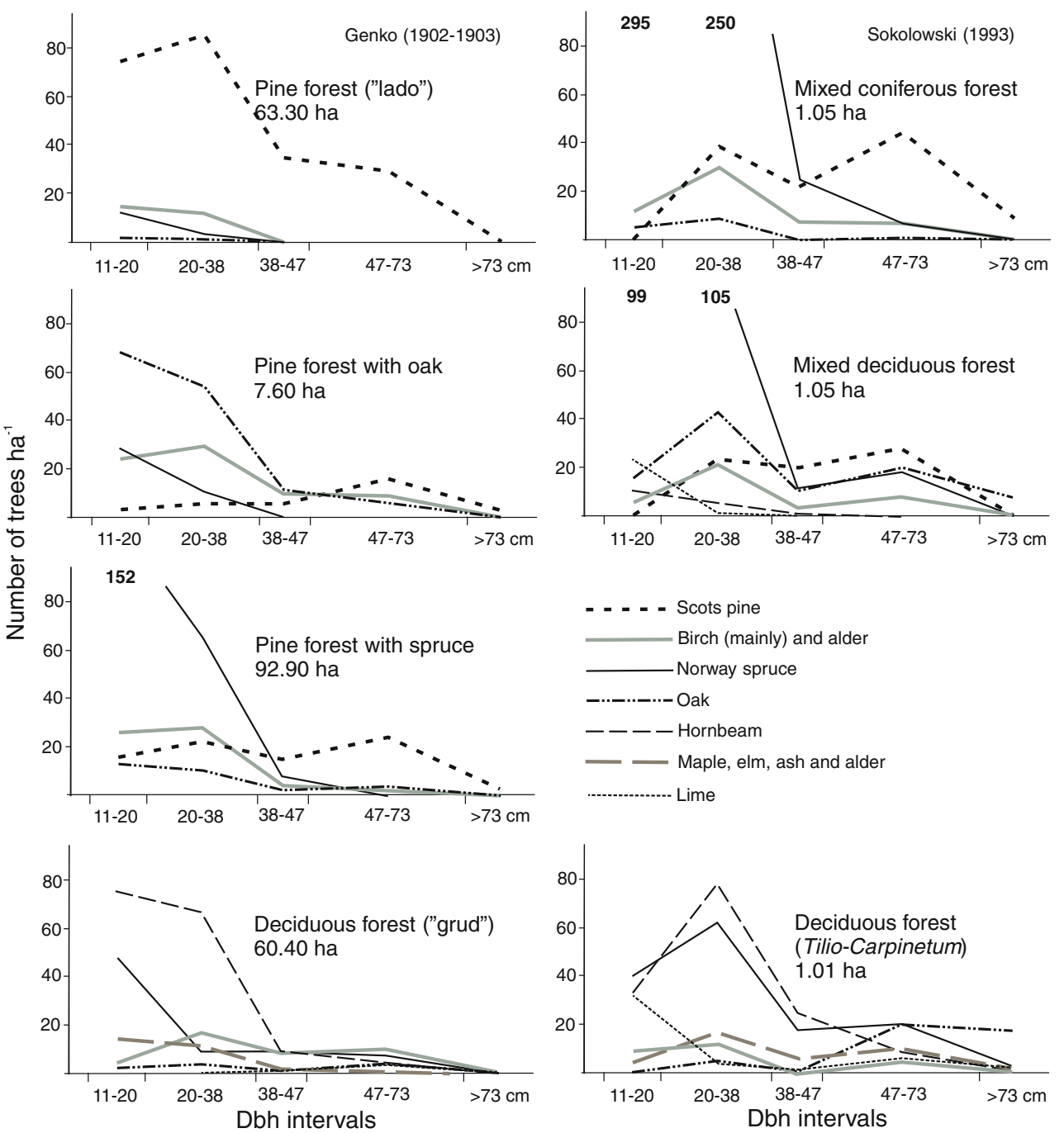

Table 4 Comparison of the percent share of forest types in the BNP preserve area based on the 1889 (Karcev 1903) and 1990 (Michalczuk 2001) forest inventories; difference significant at $p=0.002,4 d f$, $G=18.392(G$ test of independence)

\begin{tabular}{lcc}
\hline & 1889 & 1990 \\
\hline Deciduous forest & 57 & 52 \\
Wet deciduous forest & 16 & 17 \\
Pine forest & 6 & 11 \\
Spruce forest & 4 & 16 \\
Bogs and swamps & 9 & 2 \\
Meadows and open habitats & 8 & 1 \\
\hline
\end{tabular}

effect of hay making, mainly on riparian meadows, which prevented forest succession (Table 4; Fig. 2). However, if only dominant categories, i.e., deciduous forest and wet deciduous forest are considered, their ratios through time do not differ significantly, reaching 57 versus $24 \%$ and 52 versus $20 \%$ in late 1800 s and in late 1900 s, respectively
$(P=0.675,1$ d.f., $G=0.176, \mathrm{G}$ test for independence; Table 4).

Basic characteristics of the oak populations

The average oak (all individuals taller than $1.3 \mathrm{~m}$ ) population density deduced from 533 sampling plots was $11.6 \mathrm{ha}^{-1}(\mathrm{SE}=0.6)$. There was no significant difference in the oak density between sampling lines and the line along the border of the narrow riparian zone (both medians $=8.6 \mathrm{ha}^{-1}$; U Mann-Whitney $Z=0.827, p=0.409$ ); nor between the edges of wide floodplain and the former fodder clearing (both medians $=0 \mathrm{ha}^{-1} ; \mathrm{Z}=0.552$, $p=0.581$ ), Table 1 . It shows that neither the recent succession on two abandoned fodder clearings (both ca. 10 hectares in size) nor the earlier succession on the verge of the wide floodplain provided suitable conditions for oak regeneration.

Explanation of the difference between abandoned fodder clearings with contemporary successful regeneration of oak 
on former agricultural fields on the outskirts of the forest (Bobiec et al. 2011b) is related to the forest preserve that was established in 1916. Subsequent to the establishment of the preserve, pioneering birch and aspen have quickly filled the gap leaving no room for the slower to establish oak. This was also about the time of the collapse of the BPF ungulate community (including bison extinction in 1919, Jędrzejewska et al. 1997); retention of the ungulate community would have retarded succession and created more suitable conditions for oak regeneration. In the case of the abandoned floodplain, it has been entirely dominated by the secondary stand of hydrophilous alder Alnus glutinosa with a certain number of ash on the riser zone (Faliński 1986).

There are also differences in oak population characteristics between forest site categories; the mesotrophic sites of mixed forests harbor a significantly higher density of oaks (median $=12.7$ trees $\mathrm{ha}^{-1}$ ) than eutrophic sites of deciduous forest (median $=6.3 \mathrm{ha}^{-1}$, U Mann-Whitney $\mathrm{Z}=-2.236, p=0.025$ ), Table 1 . Although this is consistent with the data provided by Sokołowski (1993), Fig. 4), particular case areas deviate from this general pattern. While the most densely populated, with 21 oaks $\mathrm{ha}^{-1}$ (significantly higher density than the deciduous forest average of $11 \mathrm{ha}^{-1}$, Chi square $=6.250, p=0.012$ ), was the 3.5-ha area of the abandoned settlement and farm (Borowik-Dąbrowska and Dąbrowski 1973; Karcev 1903, Fig. 2), the scarcest population, with 5 oaks ha $^{-1}$ (significantly lower than the deciduous forest average, Chi square $=4.500, p=0.034$ ), was in the $\mathrm{B}$ area. With 16 oaks $\mathrm{ha}^{-1}$ the $\mathrm{A}$ area was more densely populated than the average deciduous forest, but the difference was not significant (Chi square $=1.850, p=0.174$ ). Also, the difference in the oak population density between the sprucedominated case area $\mathrm{C}$, with 12 oaks ha $^{-1}$, and mesotrophic sites on average, with 17 oaks ha $^{-1}$, was not statistically significant (Chi square $=1.720, p=0.189$ ).

The one-way ANOVA revealed significant differences in average oak dbh between the distinguished site categories $(F=104.954, d f=9, p<0.001)$. In particular, the trees from mesotrophic sites had significantly smaller diameters $(52 \mathrm{~cm}, \mathrm{SE}=1.2)$ than those from eutrophic sites $(74 \mathrm{~cm}, \mathrm{SE}=1.7)$. The differences between topological categories were less obvious due to small sample size (and, therefore, broad SE range) along the edges of former clearing and floodplain (Table 1).

In the following subchapters, I contrast the empirical data representing different forest types and case areas with the historic disturbance regimes: prescribed burning (case area $\mathrm{C}$ ), protoindustries (case area $\mathrm{F}$ ), game management (case area $\mathrm{A}$ ), and preservation (case area $\mathrm{B}$ ).

\section{Forest recovery after fire management}

The present oak dbh distribution in the case area C, representing mixed stands on mesotrophic sites, differs substantially from the A, B, and F distributions on rich sites due to the noticeably large number of saplings (Fig. 5).
Fig. 5 Dbh frequency distribution of oaks in case plots versus average frequency distribution in deciduous (a, b, f) and mixed forest (c) habitats. Bars represent the distributions for 2010: average based on the data from $100 \times 20$-m plots (transparent) and particular case plots (gray); the lines are the historic distributions reconstructed on the basis of the average dbh increments in time intervals (tree mortality was not considered). See Fig. 1 for the location of plots
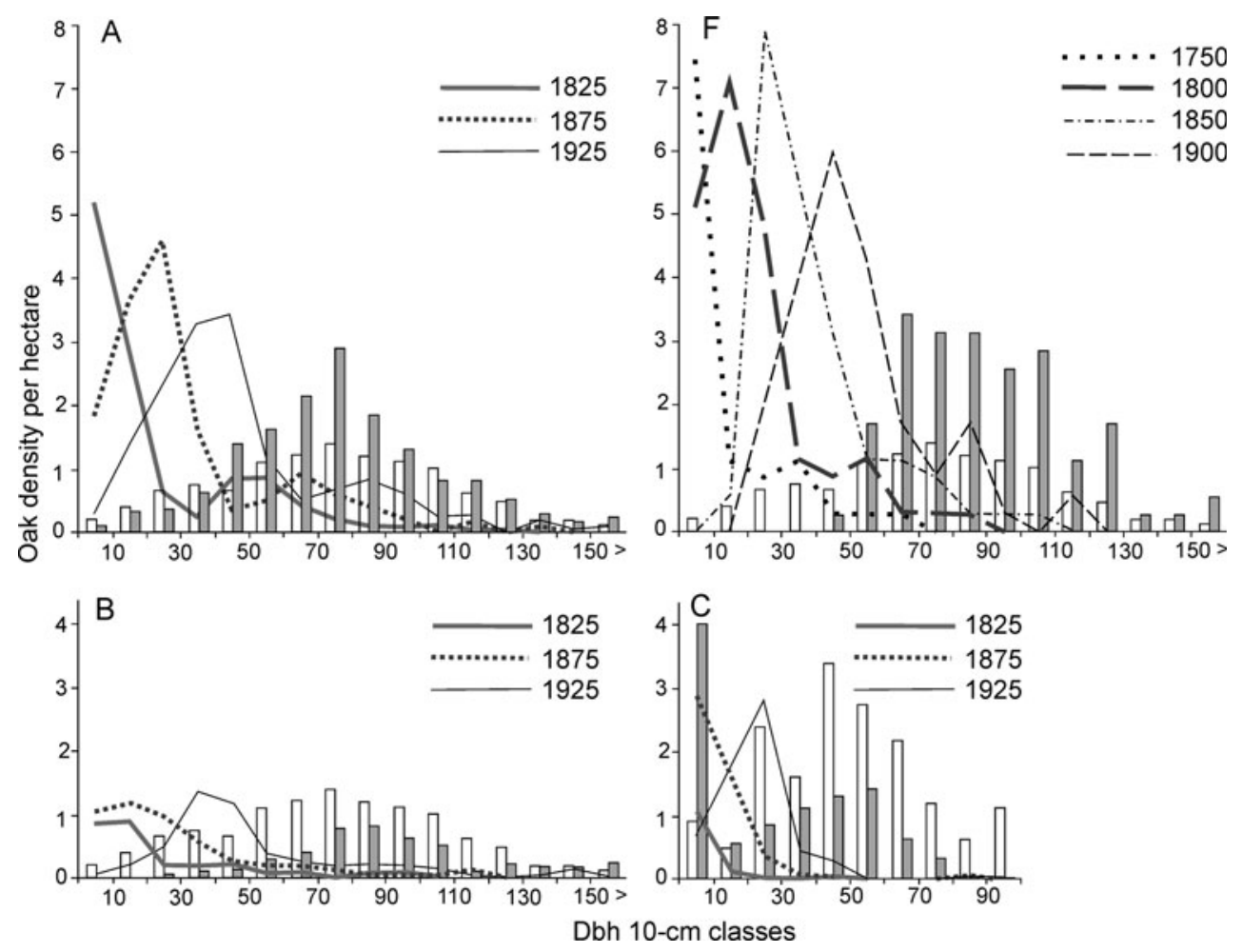
The subpopulation of C area's cored oaks was a good representation of the overall area's dbh structure (no significant difference in average dbh if saplings thinner than $7 \mathrm{~cm}$ were excluded). The reconstruction of the historic dbh distributions, based on three average ring widths (depending on diameter category, Table 2), shows that older oaks (without saplings) are on average younger than in other case areas. The distribution line representing 1875 reflects the highest level of recruitment to the lowest dbh class (Fig. 3c, 5c).

With several pines scarred by multiple fires (Fig. 6a), area $\mathrm{C}$ should be considered to be an example of sprucedominated stands developed from pine forest (Table 3; Fig. 4) after the ban on fire imposed in 1820s (Genko 1902-1903).

While most of older oaks occur in the stand dominated by 120 -year-old spruce on meso-eutrophic site, contemporary regeneration is greatest in the area dominated by the 90 -year-old spruce on slightly poorer, meso-oligotrophic sites (Fig. 3c). It is possible that immediately after the release from fire, oak gained a competitive advantage on slightly richer sites allowing it to secure a substantial portion of the canopy in pine forest with oak (Genko 19021903; Table 3). As succession progressed, however, spruce regained its competitive advantage and became the dominant species (Fig. 3c).

Based on the age structure of trees on the meso-oligotrophic site, it can be hypothesized that succession was abruptly ceased following a stand replacing disturbance (most probably fire) in the late 1800s and that oak could not withstand vigorous spruce regeneration. During the last 10-20 years, this 90-year-old spruce stand has been undergoing patchy decline accelerated by the outbreak of the bark beetle, Ips typographus (Bobiec and Bobiec in press). It is in large openings (from ca. 1,000 to ca. $30,000 \mathrm{~m}^{2}$, Bobiec and Bobiec in press) where successful oak regeneration occurs (Fig. 3c, 6b). The present oak competitive advantage is possibly a result of several factors, including increased access to solar radiation from a more open canopy, and site enrichment caused both by the steady warming of the climate since the early 1800 s (Kowalski 1991) and increase in nitrogen from air pollution (Malzahn 2002). Protection by structures such as the numerous spruce logs can also lead to more successful oak regeneration (Bobiec 2002b; Bobiec et al. 2011a).

\section{Effect of forest protoindustries}

The irregular shape of the dbh distribution, available historic data, and remaining artifacts (kiln mounds in the north and recognizable flat field beds in the south-eastern part of the area) suggest a specific development pattern of the dense oak population in $\mathrm{F}$ case area related to historic industrial and agricultural activity (Figs. 3f, 5f).

The reconstruction of the historic dbh distributions, based on three average ring widths (specific for $\leq 60$, $>60-80$, and $>80-\mathrm{cm}$ dbh categories-Table 2), shows that the most intense recruitment to the $0-10-\mathrm{cm}$ dbh class
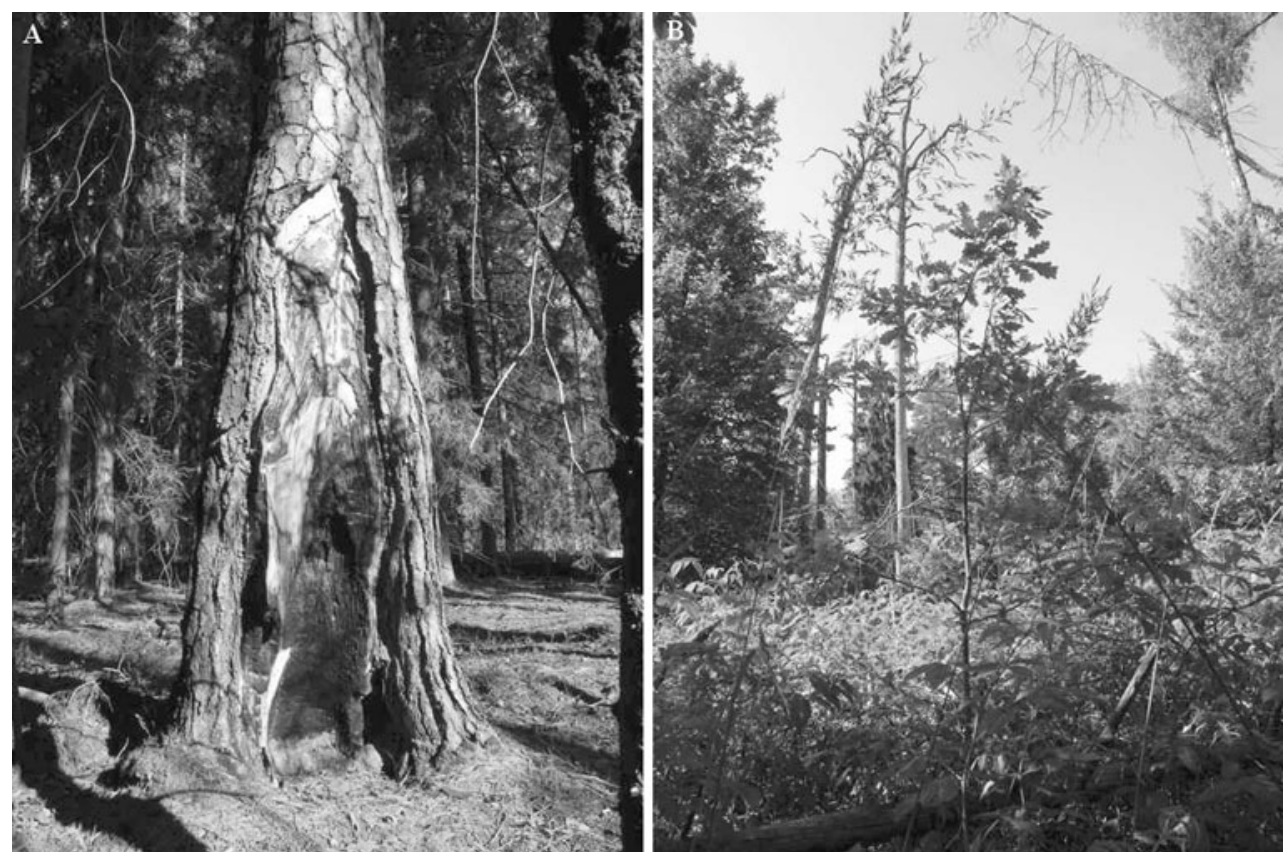

Fig. 6 Case area C. a Fire scarred pine with visible chopping marks; b Oak sapling (approx. $2 \mathrm{~m}$ tall) in a fragment of the decay phase of the 90-year-old spruce stand (summer 2010) 
took place prior to 1750 and that 100 years later the ingrowth to the current oak population had been completed (Figs. 3f, 5f).

Both timing and the length of the oak regeneration wave correspond with the historic evidence. According to recently revealed archives, Jan III Sobieski (the King of Poland) opened the BPF to almost unlimited potash, tar, and pitch production in the late 1600s (Jędrzejewska and Samojlik 2004). This opportunity encouraged numerous people to settle in the forest and start full-scale extraction of forest resources (T. Samojlik, pers. comm.). The close proximity of several likely kiln mounds (Fig. 3f) to the abandoned fields supports the hypothesis of the self-sufficient small farm with a potash (tar, pitch) factory in its backyard.

Ten years later, the royal decision was withdrawn and forest industry banned (Jędrzejewska and Samojlik 2004). The noticeably older oaks in the northern part of the area (Fig. 3f) could have emerged in the process of the forest succession following the ban. However, it is possible that the farm continued to operate during the next few decades and was abandoned only in 1760-1790s as a result of the land-reclamation programme aimed at exchanging all inner forest land concessions for external estates (Hedemann 1939; Samojlik and Jędrzejewska 2004). Perhaps the younger cohort of oaks was established after the final abandonment of the farms in the late 1700s as a result of processes similar to those observed on the abandoned fields along the BNP southern border in the young successional woodland area (Bobiec et al. 2011b).

\section{Influence of game management}

The NW part of the BPF, including today's BNP, is dominated by eutrophic sites of rich deciduous forest (Table 4; Fig. 2). The high productivity of such habitats made them particularly useful for fostering big game, especially bison for use by the royal families. Although the acreage and position of the royal game preserve where other types of activities were forbidden (Hedemann 1939), is beyond reconstruction, N. Genko's remarks on the fence, splitting the BPF into "bison" and "non-bison zones," support the supposition that areas of today's BNP and the historic preserve at least partly overlap. The internal part of the fence encircled the Białowieża village (Genko 19021903), i.e., the area directly neighboring with the BNP.

According to Samojlik and Jędrzejewska (2004), supplementary winter feeding of bison in BPF was initiated in 1700. Since then it has been a standard of the BPF protection system and could have played a key role in sustaining a vital population of bison in the time of substantially lower temperatures during the little ice age. It is worth remembering that red deer, contemporarily the major BPF browser, had gone extinct in the BPF in the mid 1700 s to be reintroduced only in the late 1800s (Jedrzejewska et al. 1997; Karcev 1903). Because of the recognized importance of the deciduous forest as bison habitat, followed by adequate legal provisions, its domination in the BNP area had to prevent or substantially limit extractive forms of forest use. As disturbances induced by the game management regime operated on a smaller (more local) scale level and with lower intensity than re-occurring fires on drier sites, their footprint is more discrete, subtler, and, therefore, more difficult to locate and quantify.

The relatively large sample size of the cored oaks in the A case area allowed division into five diameter categories. The use of five average ring widths specifically for $\leq 40$, $>40-60,>60-80,>80-100$, and $>100-\mathrm{cm}$ dbh categories (Table 2) increased the hypothetical reliability of the reconstruction of oak dbh historic distributions.

The reconstructed evolution of the oak dbh structure reflects transition from a multi-layer stand model (extremely skewed, Podlaski and Zasada 2008) to the current bell-shaped distribution of a "stand of the past" (Fig. 5a). Although the most efficient regeneration "wave" took place prior to 1825 , both the line of 1875 (Fig. 5a) and tree ring data (Fig. 3a) show that, though at lower rate, regeneration continued throughout later decades of the 1800 s, to be largely completed in early 1900s.

Several shallow (a dozen-or-so centimeters deep) and straight (from a few to a dozen-or-so meters long) troughs that I identified in the northern half of the area (Fig. 3a) are most probably the remnants of salt-licks made of grooved logs partly dug in the soil and filled with salty clay, as described by Karcev (1903). This would suggest that the A area was indeed the location of several bison feeding facilities in 1800s (Fig. 2, Karcev 1903). Karcev (1903), however, does not provide any information about the time they were established. If this took place in early 1800 s (beginning of the Russian system of bison protection, Genko 1902-1903), it would coincide with the regeneration wave depicted by the dbh reconstruction line of 1825 (Fig. 5a).

Game management was not limited to the construction and use of feeding racks, hay sheds, and salt-licks. Graminoid promotion techniques (including occasional spring burning of dry herbs and slash, Karcev 1903), occasional mowing, removal of shrubs, and steady increase of ungulate pressure could have resulted in more advantageous conditions for oak regeneration.

The initiation of the decline in oak recruitment coincides with the peak in the bison population (more than 1500 individuals, Genko 1902-1903; Table 3) reached in 1850-1860. This likely led to local heavy concentrations of bison around feeding stations providing fodder from October to April (Karcev 1903). Such behavior would have 
lasted until the collapse of the game management system in early 1900s, despite a substantial decrease of bison population in 1860s (Genko 1902-1903; Table 3). Observations of contemporary feeding stations located outside the BNP preserve (substantially fewer than in the 1800s), where heavy winter concentrations of bison prevent tree regeneration (Fig. 7), seem to support that hypothesis.

Neither in the reviewed literature nor in the field did I find evidence that would corroborate the "grazing theory": a very high pressure of large ungulates coupled with presence of unpalatable shrubs serving as "nurse" plants (Vera 2000), to explain abundant oak regeneration during the last 300 years in the BPF. Even during the period when bison populations were the highest (in 1850s) in the BPF, those numbers were on average at least 20-fold lower in ungulate biomass than the figures suggested by F. W. M. Vera as necessary for oak regeneration (190-720 kg ha Vera 2000). Only in the 1890 s was grazing heavier due to livestock wood pasturing in the peripheral parts of the forest (Genko 1902-1903; Karcev 1903). However, relatively small numbers of oaks have recruited during that period. The only thorny shrub that I encountered in the whole BNP study area was a specimen of hawthorn ( $\mathrm{Cra}$ taegus monogyna) on the former fodder clearing (Fig. 2). However, because those birch- and aspen-overgrown areas (that are gradually being replaced by hornbeam and lime) were almost devoid of oaks, no positive effect on oak regeneration can be ascribed to hawthorn.

In addition to the supposed positive effect of intermediate levels of bison grazing one should also consider the effects of the absence of red deer, the major browser in the twentieth century (6.0 individuals $\mathrm{km}^{-2}$ according to the last estimate in 2008, T. Borowik, J. Borkowski, W. Jędrzejewski, unpubl. data), for 150 years (extinct in 1750,

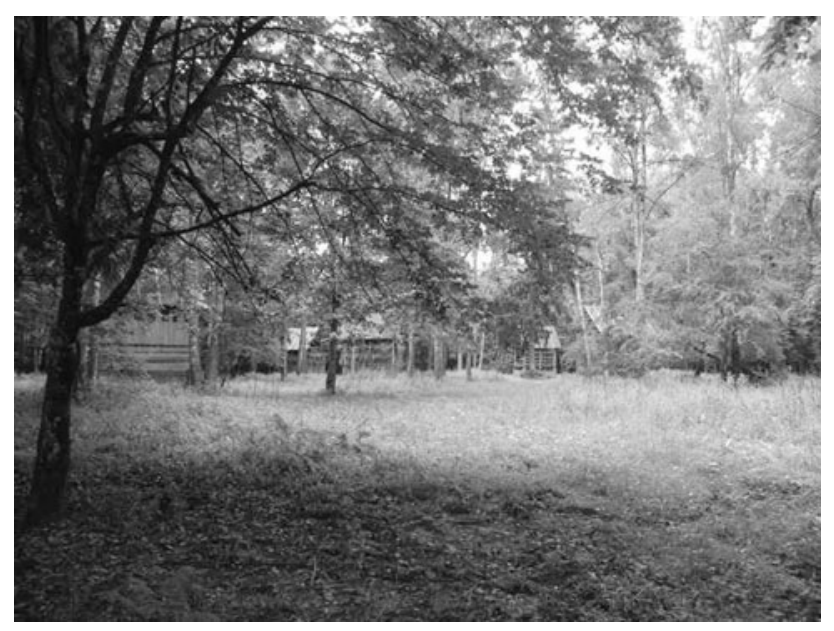

Fig. 7 Contemporary bison feeding area in the managed part of the BPF: tree (including oak) regeneration prevented by winter heavy concentrations of bison re-introduced in the late 1800s). However, based on the proxy observations in the early successional woodlands, browsed by red deer (Bobiec et al. 2011b), we can infer that it was not an impediment to successful oak regeneration in disturbed areas, characterized by low canopy cover and abounding in vegetation of higher than of oak preference to deer.

\section{Preservation}

Although the contemporary bison density on the Polish site of the BPF is comparable to that of mid 1800s (473 at the end of 2010 on $40 \%$ of the BPF, inf. from BNP, vs. ca. 1500 in 1850s in the whole BPF, Genko 1902-1903), the effect of bison grazing on ecosystems of the BNP preserve is weak compared to intensive game management practices of the 19th century.

Lack of disturbances described in previous subchapters gradually increases the competitive advantage of shadetolerant trees, particularly hornbeam and lime. The longer the period of undisturbed development, the fewer intolerant species manage to recruit and contribute to the forest canopy.

The northwestern part of the B area, a relatively vast block of forest with few old oaks (Fig. 3b), is probably a good example of a forest community with a long history of natural, undisturbed development. Although relatively poor tree ring data made the age reconstruction less reliable than in case area $\mathrm{A}$, the shape of the present dbh distribution indicates that the $\mathrm{B}$ population is older than in $\mathrm{A}$ (Fig. 5a, b).

Even though data from 533 systematic plots do not reveal a complete spatial pattern of the oak population in the BNP preserve, we can expect that spatial clusters of low oak density plots represent larger blocks of the ecosystem, comparable to the described part of case area B. Similarly, clusters of plots with high oak density should be interpreted as hypothetical representations of forest blocks that had the necessary level of disturbance in the recent past (1700-1800s) for oak regeneration. As it was shown, all three cases of deciduous forest had received unnoticeable amount of oak recruitment to the $0-10-\mathrm{cm}$ dbh class since the start of preservation in 1916 (Fig. 5a,b,f).

The historic disturbance regimes providing advantageous conditions for oak regeneration were terminated shortly after the reintroduction of red deer, the major BPF browser. Due to supplementary feeding and effective prosecution of wolves, deer population before World War I reached more than five individuals $\mathrm{km}^{-2}$. This should certainly have affected the regeneration of deciduous species in the forest. During the war, however, deer were almost extinct and until 1950 have merely recovered to one individual $\mathrm{km}^{-2}$ (Jędrzejewska et al. 1997). 
Synthesis

This analysis of the overall BNP oak population and its local subpopulations provide a consistent picture of the forest's recent past, congruent with the results of the 1889's forest survey (Genko 1902-1903) and the forestry expert's descriptive account of the 1820s (Brincken 1826). This is the picture of a forest developed under a substantial influence of human activity (Fig. 8). The large and diverse population of surviving oaks in the preserved BNP area has proved to contain rich information on the forest in the past.

The rich forest sites with high oak populations are relics of stands shaped by certain kinds of human activity that efficiently reduced competition of shade-tolerant species. Forest succession on abandoned fields, recovery of ancient forest industry areas (charcoal, potash, and tar), hay making, and activities aimed at habitat improvement to increase bison forage should have fostered oak as well as pioneering short living trees. Two case areas $\mathrm{A}$ and $\mathrm{F}$, presented in the study, are examples of this pattern. On the other hand, larger blocks of deciduous forest with no or few oaks should be regarded as areas that have the longest history of undisturbed, spontaneous development. Under local conditions defined by soil, hydrology, climate, as well as by ecological characteristics of particular tree species, shadetolerant hornbeam and little-leaf lime (accompanied by Norway maple and wych elm, U. glabra), and Norway spruce, tend to absolutely dominate stands in the longlasting, dynamic equilibrium (quasi climax) stage (Paczoski 1930; Bobiec et al. 2000). Solitary oaks found in such areas can be either remnants of old, disintegrated cohorts, established in a similar way to the more recent cohorts known from $\mathrm{A}$ and $\mathrm{F}$ cases, or products of a low-intensity stochastic regeneration.

Because of the pervasive influence of frequent ground fires on poorer soils (Niklasson et al. 2010; Samojlik and

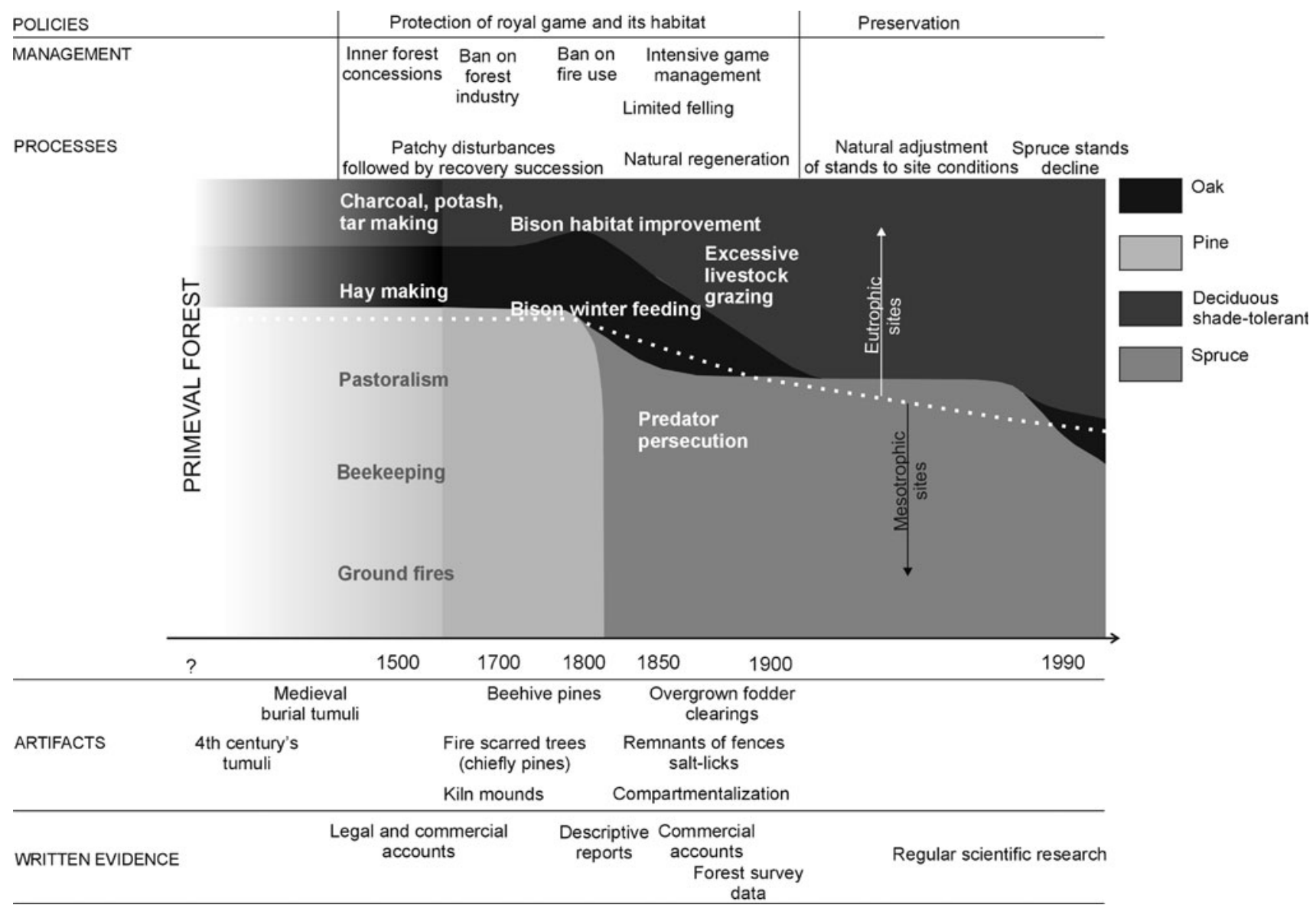

Fig. 8 Conceptual model of forest development in BPF: the intensity of tree regeneration is represented by the relative proportion of black and gray areas (for simplification, regeneration of spruce in deciduous forest was not considered), natural and anthropogenic factors. The larger initial share of poorer mesotrophic sites was partly caused and maintained by regular ground fires leading to soil degradation; after the ban on fire, the process of site regeneration began and the recent phytosociological studies indicate that site enrichment has been a continuous trend throughout the 20th century. In addition to current and historic data, the model has been based on information from numerous publications (Brincken (1826); Genko 1902-1903; Hedemann 1939; Borowik-Dabrowska and Dabrowski 1973; Paluch 2002; Samojlik and Jędrzejewska 2004) 
Jędrzejewska 2004), the history of substantial oak regeneration on mesotrophic sites is much shorter than on rich sites, typical for Tilio-Carpinetum. Regeneration only occurs after the ban on burning in the early 1800s. This long but more recent period free from fire permitted oak and other species to establish in areas formerly dominated by fire-resistant pine. The final recruitment success of oak depended on its local competitive abilities in relation to other species, in particular spruce. The data from the case area $\mathrm{C}$ suggest that oak had the advantage over spruce on slightly richer, meso-eutrophic sites (habitats of today's mixed deciduous forests), while spruce won on poorer, meso-oligotrophic sites (habitats of today's mixed-coniferous forests) (Fig. 3c). Today, a new regeneration wave of oak is occurring in areas affected by the decline of spruce-dominated stands (Bobiec and Bobiec in press; Bobiec et al. 2011a). This recruitment success can be attributed to more light in the open canopy and habitat improvement favorable to oak, including nitrogen enrichment reflected by great abundance of raspberry Rubus idaeus and substantial presence of the even more nitrophilous nettle Urtica dioica. As suggested by Bobiec et al. (2011b), palatable raspberries may substantially reduce the relative attractiveness of tanninrich young oaks for browsers, while fallen spruce logs additionally provide protected regeneration sites.

The influence of historic forest use had different effects on forest characteristics depending on site quality (Fig. 8). On poorer and dryer, mesotrophic sites, frequent burning led to homogenization of communities due to soil degradation giving an overwhelming competitive advantage to pine. On rich, eutrophic sites, anthropogenic disturbances allowed substantial and continuous presence of earlier successional stages, favoring intolerant species. Natural development after the cessation of the described historic factors led to diversification of communities on poorer sites (at the expense of pine) and to homogenization on rich sites (at the expense of intolerant species).

\section{Conclusions}

- The current strong position of oak in the canopy of oldgrowth stands of the Białowieża National Park preserve cannot be explained by the natural dynamics observed during the last 90 years.

- Canopy oaks on poorer and drier sites emerged as the habitat recovered following cessation, in the 1820 s, of the long series of ground fires. Elimination of ground fire reduced the competitive advantage of pine. Unlike the whole Białowieża forest, however, most of the BNP preserve area was not subject to fire management and thus oaks only locally benefited from the cessation of fire.
- On the richer sites of deciduous stands, high oak density areas are related to various kinds of local maninduced disturbances and subsequent response of natural processes. Two case studies provided evidence of spatial and temporal correspondence of oak age structure with: (1) the historic small settlement and local forest protoindustry (late 1600s-late 1700s) and (2) the application of game management practices including bison feeding stations and, most probably, bison habitat improvement measures, such as spring litter and slash burning and mowing (from 1700 at earliest to 1915 at latest).

- Forested areas with few or no oaks likely have been on the longest trajectory of natural, undisturbed by man, development.

- Under the existing preservation regime, the culturally modified forest habitats continue to develop. This development involves increasing domination by shadetolerant species on richer and wetter habitats and progressing encroachment of deciduous species into former coniferous stands on poorer habitats. In the latter case, successful oak saplings recruitment is being observed in large gaps resulting from disintegration of spruce stands. Even though the study area represents the most natural temperate forest ecosystem in lowland Europe (considering the time period of unceasing spontaneous development), it should not be considered a remnant of a truly primeval forest that developed after the last ice age. This forest, during 400 years of royal protection, was affected by long-lasting internal concessions (e.g., beekeeping, charcoal, potash and tar production, farmsteads), prescribed fires, and 120 years of Russian style intensive game management thus was far from being a natural "self-controlled" ecosystem.

- Also, numerous older archeological artifacts (both medieval and antique), excavated in the BPF area (Götze 1929; Krasnodębski et al. 2005, 2008), suggest that even prior the royal system of forest use and protection, this was not an untouched forest. Only systematic paleoecological studies can verify if there are still remaining pockets of the aboriginal unmodified ecosystem.

- While historic culturally modified communities developed following anthropogenic modifications of the forest without further human intervention, current forestry practices neither mimic those historic activities nor reflect natural processes. In particular, sanitary spruce felling aimed to control the bark beetle population, counteracts natural ecosystem adaptation to changing environmental conditions, manifested by spontaneous, successful oak regeneration. Because of relatively poor representation of mesotrophic sites in the BNP area, focusing on these habitats should be an 
important priority of the conservation plan of the Białowieża Natura 2000 site that encompasses the entire Polish BPF.

Acknowledgments I am particularly indebted to Markus Feijen for his invaluable help in the field work and numerous inspiring ideas. Many thanks to Bastien Pascal, Jean-Baptist Reboul, Mateusz, Marek and Tomek Bobiec, Kamil Pilch, and Łukasz Wilk for their great assistance in the field work. I would like to thank to Dr Mats Niklasson, Dr Ewa Zin, and Dr Igor Drobyshev for the dendrochronological advice. I am very thankful for encouragement and helping comments of two reviewers. The final version of the manuscript was developed with the friendly help of Dr William F. Laudenslayer, providing stimulating comments and English check. The wonderful hospitality of the Białowieża Geobotanical Station of Warsaw University was an invaluable asset to research and made the work much more enjoyable. The study was financed through the Polish public resources dedicated to research in 2008-2010 (Ministry of Science and Higher Education, grant NN3092955). The tree coring was performed with the permission of the Minister of Environment and the Białowieża National Park.

Open Access This article is distributed under the terms of the Creative Commons Attribution License which permits any use, distribution, and reproduction in any medium, provided the original author(s) and the source are credited.

\section{References}

Bernadzki E, Bolibok L, Brzeziecki B, Zajączkowski J, Żybura H (1998) Compositional dynamics of natural forests in the Białowieża National Park, northeastern Poland. J Veg Sci 9: 229-238

Bobiec A (2002a) Bialowieza Primeval Forest: the largest area of natural deciduous lowland forest in Europe. Int J Wilderness 8:33-37

Bobiec A (2002b) Living stands and dead wood in the Bialowieza Forest: suggestions for restoration management. For Ecol Manage 165:121-136

Bobiec A (2007) The influence of gaps on tree regeneration: a case study of the mixed lime-hornbeam (Tilio-Carpinetum Tracz. 1962) communities in the Białowieża Primeval Forest. Pol J Ecol $55: 441-455$

Bobiec A, Bobiec M. Influence of spruce decline in stands of the Białowieża National Park on natural oak regeneration. Sylwan, in press (in Polish with English summary)

Bobiec A, van der Burgt H, Meijer K, Zuyderduyn C, Haga J, Vlaanderen B (2000) Rich deciduous forests in Białowieża as a dynamic mosaic of developmental phases: premises for nature conservation and restoration management. For Ecol Manage 130:159-175

Bobiec A, Jaszcz E, Wojtunik K (2011a) Oak (Quercus robur L.) regeneration as a response to natural dynamics of stands in European hemiboreal zone. Eur J For Res 130:785-797

Bobiec A, Kuiper DPJ, Niklasson M, Romankiewicz A, Solecka K (2011b) Oak (Quercus robur L.) regeneration in early successional woodlands grazed by wild ungulates in the absence of livestock. For Ecol Manage 262:780-790

Borowik-Dabrowska M, Dạbrowski MJ (1973) Natural and anthropogenic succession of the Białowieża National Park vegetation. Archeol Pol 18:181-200 (in Polish with English summary)

Brzeziecki B (2008) Long-term dynamics of natural stands on the example of two forest communities of the Białowieża National
Park: Pino-Quercetum and Tilio-Carpinetum. Stud Nat 54:9-22 (in Polish with English summary)

Ellenberg H (1988) Vegetation ecology of Central Europe. Cambridge University Press, Cambridge, MA

Faliński JB (1986) Vegetation dynamics in temperate lowland primeval forests, ecological studies in Białowieża Forest. Dr W Junk Publishers, Dordrecht

Genko N (1902-1903) Kharakteristika Belovezhskoi Pushchi i istoricheskiya o nei danya (Characteristics of the Białowieża Primeval Forest and its historical data). Lesnoj Zhurnal 22(5): 1014- 1-56; 22(6):1269-1302; 23(1):22-56 (in Russian)

Götze A (1929) Archäologische Untersuchungen im Urwalde von Bialowies, in: Beiträge zur Natur- und Kulturgeschichte Lithauens und angrezenden Gebiete, Abhandlungen des math.-naturwiss. Abteilung des Bayerische Akademie des Wissenschaften. Suppl München 11-14:511-550

Hedemann O (1939) L'histoire de la Forêt de Białowieża (jusqu'a 1798). Instytut Badawczy Lasów Państwowych, Warszawa (in Polish with French Resumé)

Jędrzejewska B, Samojlik T (2004) Kontrakty Jana III Sobieskiego z lat 1675-1686 w sprawie dzierżawy i użytkowania Leśnictwa Białowiesiego [The 1675-1686 contracts of Jan III Sobieski concerning lease and use of the Białowieża forest district]. Kwart Hist Kult Mater 52:321-330 (in Polish)

Jędrzejewska B, Jędrzejewski W, Bunevich AN, Miłkowski L, Krasiński ZA (1997) Factors shaping population densities and increase rates of ungulates in Białowieża Primeval Forest (Poland and Belarus) in the 19th and 20th century. Acta Theriol 42:399-451

Karcev G (1903) Belovezhskaya Pushcha. Ee istoricheskii ocherk, sovremennoe okhotniche khozajstvo i vysochaishe okhoty $\mathrm{v}$ Pushche [Białowieża Primeval Forest: a historical sketch, contemporary management and imperial hunts]. A Marks, Sankt Petersburg (in Russian)

Kowalski M (1991) Climate: a changing component of forest site. Folia For Pol, Ser A 33:26-34

Krasnodębski D, Samojlik T, Olczak H, Jędrzejewska B (2005) Early medieval cemetery in the Zamczysko range, Białowieża Primeval Forest. Spraw Archeol 57:554-583

Krasnodębski D, Dulinicz M, Samojlik T, Olczak H, Jędrzejewska B (2008) A cremation cemetery of the Wielbark culture in Kletna range (Białowieża National Park, Podlasie Provence). Wiad Archeol 60:361-376 (in Polish with English summary)

Malzahn E (2002) The monitoring of threat to and pollution of the forest environment in Białowieża Primeval Forest. Kosmos 51:435-441 (in Polish with English summary)

McDonald JH (2009) The handbook of biological statistics. http://udel.edu/ mcdonald/statintro.html Accessed 16 December 2011

Michalczuk C (2001) Forest habitats and treestands of Białowieża National Park. Phytocoenosis, Suppl Cartogr Geobot 13 N.S., Warszawa-Białowieża

Niklasson M, Zin E, Zielonka T, Feijen M, Korczyk AF, Churski M, Samojlik T, Jędrzejewska B, Gutowski JM, Brzeziecki B (2010) A 350-year tree-ring fire record from Białowieża Primeval Forest, Poland: implications for Central European lowland fire history. J Ecol 98:1319-1329

Olszewski JL (1986) The role of forest ecosystems in modifying local climate of the Białowieża Primeval Forest as revealed by air temperature characteristics. Ossolineum, Wrocław—Eódź (in Polish with English summary)

Paczoski J (1930) Die Waldtypen von Białowieża. Państwowa Rada Ochrony Przyrody, Kraków (in Polish with German summary)

Paluch R (2002) Direction and rate of successional changes in the strict reserve of the Białowieża National Park. Kosmos 51:453-461 (in Polish with English summary) 
Peterken GF (1996) Natural Woodland. Ecology and conservation in northern temperate regions. Cambridge University Press, Cambridge

Podlaski R, Zasada M (2008) Comparison of selected statistical distributions for modelling the diameter distributions in nearnatural Abies-Fagus forests in the Świętokrzyski National Park (Poland). Eur J For Res 127:455-463

Rinn F (2003) TSAP-Win ${ }^{\mathrm{TM}}$ Time Series Analysis and presentation for dendrochronology and related applications version 0.53 for Microsoft Windows 98, 2000, XP. Rinntech, Heilderberg

Samojlik T, Jędrzejewska B (2004) Utilization of Bialowieza Forest in the times of Jagiellonian dynasty and its traces in the contemporary forest environment. Sylwan 148:37-50 (in Polish with English summary)

Sokal RR, Rohlf FJ (1995) Biometry: the principles and practice of statistics in biological research, 3rd edn. W.H Freeman, New York
Sokołowski AW (1993) Phytosociological characteristics of forest communities in the Białowieża National Park. Park Nar Rezerw Przyr 12:5-190 (in Polish with English summary)

Tomiałojć L, Wesołowski T (2005) The avifauna of the Białowieża Forest: a window into the past. Br Birds 98:174-193

Vera FWM (2000) Grazing ecology and forest history. CABI, Wallingford

von Brincken J (1826) Mémoire Descriptif sur la forêt impériale de Białowieża, en Lithuanie. Annoté et commenté par Daszkiewicz P, Jędrzejewska B, Samojlik T, Glücksberg, Warszawa (reprint 2004 by Editions Epigraf, Paris, in French)

Watt AS (1919) On the cause of failure of natural regeneration in British oakwoods. J Ecol 7:173-203 